\title{
Penerapan Model Pembelajaran Inkuiri Terbimbing untuk Meningkatkan Hasil Belajar Peserta Didik Pada SMPN 22 Konawe Selatan

\author{
Desa Putu Sri $^{1)} *$, Luh Sukariasih ${ }^{2)}$, Vivi Rufa Mongkito ${ }^{3)}$ \\ 1)* Mahasiswa Pendidikan Fisika Universitas Halu Oleo \\ ${ }^{2), 3)}$ Dosen Pendidikan Fisika Universitas Halu Oleo
}

*Korespondensi Email:desaputusri@gmail.com

\begin{abstract}
Abstrak: Penelitian ini bertujuan Memperoleh data dan gambaran hasil belajar fisika peserta didik kelas eksperimen dan kelas kontrol pada sub materi getaran, gelombang dan bunyi. Populasi penelitian ini adalah seluruh peserta didik kelas VIII SMPN 22 Konawe Selatan di Kabupaten Konawe Selatan yang berjumlah 206 orang. Teknik pengambilan Sampel penelitian ini adalah random sampling sehingga diperoleh dua kelas yaitu kelas eksperimen $\left(\right.$ kelas $\mathrm{VIII}_{\mathrm{B}}$ ) dan kelas kontrol $\left(\mathrm{VIII}_{\mathrm{C}}\right)$. Berdasarkan analisis data dan pembahasan diperoleh kesimpulan Gambaran hasil belajar tes awal dan tes akhir peserta didik dengan model pembelajaran inkuiri terbimbing diperoleh nilai rerata 42,86 dan standar deviasi 14,1. Untuk tes akhir diperoleh nilai rerata 65,18 dan standar deviasi 10,4 hal ini menunjukkan bahwa lebih besar dibandingkan dengan model pembelajaran konvensional. Sehingga tidak ada perbedaan antara nilai rerata hasil tes awal peserta didik kelas eksperimen dan kelas kontrol. Untuk nilai rerata N-gain peserta didik kelas eksperimen lebih tinggi dari pada kelas kontrol.

Kata Kunci: Pembelajaran Inkuiri Terbimbing, Pembelajaran Konvensional, Hasil Belajar Peserta Didik

Abstract: This study aims to obtain data and descriptions of physics learning outcomes of students in the experimental class and control class in the sub-material of vibration, waves and sound. The population of this study were all students of class VIII SMPN 22 Konawe Selatan in Konawe Selatan, totaling 206 people. The sampling technique for this research was random sampling so that there were two classes, namely the experimental class (class VIIIB) and the control class (VIIIC). Based on the data analysis and discussion, it was concluded that the description of the learning outcomes of the preliminary test and the final test of students with the guided inquiry learning model obtained a mean value of 42.86 and a standard deviation of 14.1. For the final test, it was obtained a mean value of 65.18 and a standard deviation of 10.4, this indicates that it is greater than the conventional learning model. So that there is no difference between the mean value of the initial test results of the experimental class and control class students. For the $N$-gain mean value of the experimental class students was higher than the control class.
\end{abstract}

Keywords: Guided Inquiry Learning; Conventional Learning; Student Learning Outcomes.

\section{PENDAHULUAN}

Model pembelajaran inkuiri terbimbing ini siswa lebih banyak aktif dalam proses pembelajarannya yang telah dikondisikan untuk dapat menerapkan berpikir dalam upaya menggali sendiri segala konsep untuk mengambil inisiatif dalam usaha memecahkan masalah, mengambil keputusan, dan melatih siswa berpikir kritis dalam permasalahan fisika. Pembelajaran inkuiri terbimbing diterapkan agar para peserta didik bebas mengembangkan konsep yang mereka pelajari. Keuntungan dari pembelajaran inkuiri terbimbing yaitu siswa belajar tentang hal-hal penting namun mudah dilakukan, siswa didorong untuk melakukan bukan hanya duduk, diam dan mendengarkan.
Peluang melakukan penemuan dengan berbagai observasi dan ekspresi.

Model pembelajaran inkuiri terbimbing ini sebelumnya sudah pernah dilakukan diantaranya Sari (2017) yang menunjukkan bahwa model pembelajaran inkuiri terbimbing sangat baik digunakan karena siswa belajar tentang hal-hal penting namun mudah dilakukan, siswa didorong untuk melakukan bukan hanya duduk, diam dan mendengarkan. Selain itu tema yang dipelajari tidak terbatas bisa bersumber dari mana saja. Menurut penelitian Amroniyah (2015) bahwa prestasi belajar peserta didik dalam pembelajaran IPA materi getaran dan gelombang melalui metode inkuiri terbimbing pada peserta didik kelas VIII MTs 
Mualimin Malebo Kandangan telah mengalami peningkatan. Penilaian dinyatakan telah menunjukkan bahwa secara nilai telah mencapai 72 dari 20 peserta didik. Ketuntasan klasikal sebesar $100 \%$ peserta didik yang mendapat nilai $70 \mathrm{ke}$ atas dapat disimpulkan telah mencapai batas tuntas.

Menurut penelitian sumarni (2017) Hasil belajar kognitif peserta didik yang menerima pembelajaran dengan model inkuiri terbimbing lebih tinggi dibandingkan peserta didik yang menerima pelajaran dengan model konvensional. Hal ini diketahui dari nilai yang diperoleh oleh kelas eksperimen dan kelas kontrol, diantaranya: nilai maksimal kelas eksperimen adalah 98. Sedangkan nilai maksimal kelas kontrol adalah 75. Menurut penelitian Putri dkk (2015) bahwa model pembelajaran inkuiri terbimbing dapat meningkatkan aktivitas belajar. Selain itu meningkatkan rata-rata hasil belajar siswa dan ketuntasan belajar. Penelitian menurut Chairinda (2017) bahwa penerapan model pembelajaran inkuiri terbimbing pada materi getaran harmonis dapat meningkatkan hasil belajar peserta didik XI-MIA 1 di SMAN 12 Banda Aceh baik dari segi ketuntasan individual maupun ketuntasan klasikal. Menurut Iswatun, dkk (2017) bahwa model pembelajaran inkuiri terbimbing dapat meningkatkan keterampilan proses sains siswa dengan peningkatan 0,52 termasuk kategori sedang serta hasil belajar kognitif siswa dengan peningkatan 0,53 termasuk kategori sedang. Model pembelajaran inkuiri terbimbing berpengaruh positif terhadap keterampilan proses sains dan hasil belajar kognitif siswa $\mathrm{r}(35)=0,554$. Besarnya pengaruh pembelajaran inkuiri terbimbing terhadap keterampilan proses sains dan hasil belajar kognitif siswa sebesar 30,69\%. Penelitian menurut Sukma (2016) terdapat pengaruh yang positif dan signifikan antara motivasi belajar siswa terhadap hasil belajar siswa kelas X SMA Negeri 11 Samarinda tahun ajaran 2014/2015 pada materi suhu dan kalor. Hasil ini disebabkan karena pada pembelajaran inkuiri terbimbing siswa dapat mengembangkan cara berpikir ilmiah yang menempatkan siswa sebagai pembelajar dalam memecahkan permasalahan dan memperoleh pengetahuan yang bersifat penyelidikan sehingga dapat memahami konsep-konesp sains.

Mata pelajaran fisika sebagai bagian dari ilmu pengetahuan alam (IPA) merupakan ilmu-ilmu dasar yang perlu diberikan kepada siswa. Keaktifan siswa dalam pembelajaran fisika sangat penting sebab pembelajaran haruslah berpusat pada siswa, bukan pada guru. Keaktifan dalam belajar fisika terletak pada dua segi, yaitu aktif bertindak secara fisik dan aktif berpikir. Pembelajaran fisika pada jenjang pendidikan dasar dan jenjang pendidikan menengah selama ini ditandai dengan pembelajaran yang didominasi oleh aktivitas guru dibandingkan aktivitas peserta didik. Hal ini sesuai dengan informasi dan hasil wawancara dari salah satu sekolah di kabupaten Konawe Selatan pada 13 November 2018 bahwa pembelajaran IPA khususnya fisika kurang efektif. Dimana peserta didik kurang aktif dalam proses pembelajaran. Karena peserta didik belum dapat menyesuaikan diri dengan penerapan model pembelajaran dalam kurikulum 2013 bahwa siswa harus lebih aktif dari pada guru pada saat proses pembelajaran berlangsung. Dari observasi awal tersebut bahwa beberapa peserta didik tidak tuntas dalam mencapai Kriteria Ketuntasan Minimal (KKM). Dari hasil belajar sekitar $78 \%$ peserta didik dinyatakan tidak lulus dan $21 \%$ peserta didik yang dinyatakan lulus.

Apabila permasalahan ini dibiarkan, maka akan menciptakan pembelajaran yang kembali berpusat pada guru, dimana peserta didik hanya akan lebih banyak mendengarkan dan mancatat penjelasan dari guru tanpa ada usaha untuk mencari informasi atau pengetahuan sendiri. Sedangkan, hal tersebut akan bertentangan dengan kegiatan pembelajaran Kurikulum 2013, dimana seharusnya peserta didik lebih aktif dibandingkan guru sehingga mampu membangun pengetahuannya sendiri dan tidak sekedar hafalan namun benar-benar memahami konsep fisika Rendahnya hasil belajar pada sub pokok materi getaran, gelombang dan bunyi merupakan suatu masalah yang perlu diselesaikan. Oleh karena itu untuk mengatasi permasalahan tersebut tentunya harus terdapat pemilihan model pembelajaran yang tepat sehingga dapat meningkatkan minat, semangat, dan kemampuan berpikir untuk memecahkan suatu permasalahan.

\section{METODE}

Penelitian ini termasuk penelitian eksperimen ciri utamanya adalah sampel yang digunakan untuk kelas eksperimen maupun sebagai kelompok kontrol diambil secara random dari populasi tertentu. Lokasi penelitian yang dipilih di SMPN 22 Konawe Selatan, Kabupaten Konawe Selatan. Penelitian ini dilaksanakan pada semester genap tahun ajaran 2018/2019. Desain penelitian yang digunakan dalam penelitian ini adalah pretest-posttest control group design (Sugiyono. 2013). Selengkapnya disajikan sebagai berikut. 


\begin{tabular}{|c|c|c|c|c|}
\hline Eksperimen & $: \mathrm{R}$ & $\mathrm{O}_{1}$ & $X$ & $\mathrm{O}_{2}$ \\
\hline Kontrol & $: \mathrm{R}$ & $\mathrm{O}_{3}$ & - & $\mathrm{O}_{4}$ \\
\hline \multicolumn{5}{|l|}{ Dengan: } \\
\hline $\mathrm{O}_{1}$ & \multirow{7}{*}{\multicolumn{4}{|c|}{$\begin{array}{l}\text { : tes awal (pre-test) yang diberikan pada kelas eksperimen } \\
: \text { tes awal (pre-test) yang diberikan pada kelas kontrol } \\
: \text { tes akhir (post-test) yang diberikan kepada kelas eksperimen } \\
: \text { tes akhir (post-test) yang diberikan kepada kelas kontrol } \\
\text { : kelompok eksperimen dan kontrol diambil secara random } \\
\text { : pembelajaran dengan model pembelajaran inkuiri terbimbing } \\
\text { : kelompok peserta didik kelas eksperimen dan kelas Kontrol } \\
\text { terpisah secara parallel. }\end{array}$}} \\
\hline $\mathrm{O}_{3}$ & & & & \\
\hline $\mathrm{O}_{2}$ & & & & \\
\hline $\mathrm{O}_{4}$ & & & & \\
\hline $\mathrm{R}$ & & & & \\
\hline X & & & & \\
\hline--- & & & & \\
\hline
\end{tabular}

Populasi dalam penelitian ini adalah seluruh peserta didik kelas VIII pada SMPN 22 Konawe Selatan

Tahun Ajaran 2018/2019 yang tersebar dari kelas VIII $_{\mathrm{A}}$ sampai VIII $_{\mathrm{G}}$.

Tabel 1. Distribusi Populasi Penelitian Peserta Didik Kelas VIII SMPN 22 Konawe Selatan Semester Genap Tahun Ajaran 2018/2019

\begin{tabular}{ccc}
\hline No & Kelas & Jumlah \\
\hline 1 & VIII $_{\mathrm{A}}$ & 32 Orang \\
\hline 2 & VIII $_{\mathrm{B}}$ & 32 Orang \\
\hline 3 & VIIIc $_{\mathrm{i}}$ & 30 Orang \\
\hline 4 & VIII $_{\mathrm{D}}$ & 30 Orang \\
\hline 5 & VIII $_{\mathrm{E}}$ & 28 Orang \\
\hline 6 & VIII $_{\mathrm{F}}$ & 29 Orang \\
\hline 7 & VIII $_{\mathrm{G}}$ & 25 Orang \\
\hline & Jumlah & 206 Orang \\
\hline
\end{tabular}

Pengambilan sampel penelitian dilakukann dengan menggunakan teknik random sampling. Sampel diambil dari populasi yang telah diuji homogenitasnya. Sampel yang homogen dapat dilihat pada Tabel 3.2 berikut. Jika populasi homogen, maka untuk menentukan kelas eksperimen dan kelas kontrol dilakukan dengan cara diundi. Dari hasil proses pengundian di perolah kelas VIII $_{B}$ sebagai kelas eksperimen dan kelas VIIIc sebagai kelas kontrol.

Variabel dalam penelitian ini terdiri atas dua yaitu variabel bebas dan variabel terikat. Variabel bebas dalam penelitian ini adalah model pembelajaran inkuiri terbimbing, variabel terikatnya adalah hasil belajar peserta didik pada materi getaran, gelombang dan bunyi. Prosedur Penelitian dan langkah-langkah yang dilakukan dalam penelitian sebagai berikut.

a) Melakukan observasi awal di SMPN 22 Konawe Selatan untuk mengetahui jumlah populasi yang dijadikan objek penelitian, nilai hasil belajar IPA fisika peserta didik dan model pembelajaran yang digunakan.

b) Mengambil data nilai ulangan peserta didik sebelum materi pokok gerak lurus, gaya berdasarkan Hukum Newton dan penerapannya untuk uji homogenitas.

c) Menyusun perangkat pembelajaran berupa silabus, RPP, dan LKPD.

d) Membuat kisi-kisi tes uji coba instrumen.

e) Menyusun instrumen tes uji coba berdasarkan kisi-kisi yang telah disusun.

f) Mengujicobakan instrumen tes uji coba pada kelas IX IPA (yang sebelumnya telah diajarkan materi).

g) Menganalisis data hasil instrumen tes uji coba pada kelas uji coba untuk mengetahui taraf kesukaran, daya pembeda soal, validitas soal dan reliabilitas soal.

h) Menentukan soal-soal tes yang akan digunakan dalam tes akhir pada kelas eksperimen dan kelas kontrol yang memenuhi syarat. 
i) Mempersiapkan alat-alat yang akan digunakan untuk kegiatan praktikum

j) Melakaukan tes awal pada kelas eksperimen dan kelas kontrol

k) Melakukan pembelajaran inkuiri terbimbing pada kelas eksperimen dan kelas kontrol dengan model lain.

1) Melakukan tes akhir pada kelas eksperimen dan kelas kontrol

m) Menganalisis hasil tes awal dan tes akhir

n) Menyusun hasil penelitian.

Instrumen yang akan digunakan untuk mengukur hasil belajar fisika peserta didik tes obyektif bentuk pilihan ganda sebanyak 20 soal, soal yang digunakan berdasarkan kisi-kisi dengan penskoran jika benar diberi skor 1 dan jika salah diberi skor 0 . Tes yang diberikan kepada kelompok kelas eksperimen sama dengan tes yang diberikan kepada kelompok kelas kontrol. Hasil belajar yang diukur adalah aspek kognitif yaitu mengingat $\left(\mathrm{C}_{1}\right)$, memahami $\left(\mathrm{C}_{2}\right)$, mengaplikasikan $\left(\mathrm{C}_{3}\right)$, dan menganalisis $\left(\mathrm{C}_{4}\right)$.
Untuk mengetahui karakteristik tes yang akan dilakukan, terlebih dahulu dilakukan validasi untuk mengetahui validitas, reliabilitas, daya pembeda, dan tingkat kesukaran soal untuk tes objektif dalam bentuk pilihan ganda tersebut.

\section{a) Validitas Item Soal}

Sebuah instrumen dikatakan valid apabila mampu mengukur apa yang diinginkan atau dengan kata lain suatu alat evaluasi disebut valid jika ia dapat mengevaluasi dengan tepat sesuatu yang dievaluasi tersebut. Uji validasi dalam penelitian ini dilakukan dengan mengkorelasikan skor masingmasing item dengan skor total yang diperoleh peserta didik melalui soal yang diujikan tersebut. Dimana soal sebelum di uji validnya berjumlah 30 butir soal, namum setelah di uji butir soal yang valid berjumlah 20 soal sehingga soal yang tidak valid berjumlah 10 butir soal. Untuk mengukur validitas soal dalam penelitian digunakan korelasi ProductMoment sebagai berikut.

Keterangan :

$$
r_{X Y}=\frac{n \sum x y-\left(\sum x\right)\left(\sum y\right)}{\left.\sqrt{\left\{n\left(\sum x^{2}\right)-\left(\sum x\right)^{2}\right\} n\left(\sum y^{2}\right)-\left(\sum y\right)^{2}}\right\}}
$$

(Arikunto. 2010)

$r_{x y}$ : koefisien korelasi antara variabel $\mathrm{X}$ dan variable $\mathrm{Y}$, dua variabel yang dikorelasikan.

$\mathrm{x}$ : skor item soal

y : skor total soal

$\mathrm{n}$ : jumlah peserta didik

Adapun kriteria pengujian sebagai berikut:

1) Jika $r_{X Y} \geq r_{\text {tabel }}$ dengan $\alpha=0,05$ maka item tersebut valid

2) Jika $r_{X Y}<r_{\text {tabel }}$ dengan $\alpha=0,05$ maka item tersebut tidak valid

\section{b) Reliabilitas Tes}

Suatu tes dapat dikatakan memiliki taraf reliabilitas yang tinggi dimana tes tersebut dapat

$$
r_{11}=\left[\frac{k}{k-1}\right]\left[\frac{V_{t}-\sum p q}{V_{t}}\right]
$$

memberikan hasil yang tetap dihitung dengan koefisien reliabilitas. Reliabilitas tes untuk butir soal obyektif ditentukan dengan rumus K-R :

Keterangan :

$r_{11}=$ Reliabilitas tes

$p \quad=$ Proporsi subyek yang menjawab item dengan benar

$q \quad=$ Proporsi subyek yang menjawab salah

$\sum \mathrm{pq} \quad=$ Jumlah hasil kali antara $\mathrm{p}$ dan $\mathrm{q}$

$\mathrm{k} \quad=$ Banyaknya butir pertanyaan

$V_{t} \quad=$ Varians total 
Tabel 2. Batasan Kategori Reliabilitas Suatu Tes

\begin{tabular}{cc}
\hline Batasan & Kategori \\
\hline $0,8<r_{11} \leq 1,0$ & Sangat Tinggi \\
\hline $0,6<r_{11} \leq 0,8$ & Tinggi \\
\hline $0,4<r_{11} \leq 0,6$ & Cukup \\
\hline $0,2<r_{11} \leq 0,4$ & Rendah \\
\hline $\mathrm{r}_{11} \leq 0,20$ & Sangat Rendah \\
\hline
\end{tabular}

c) Daya Pembeda Tes

Daya pembeda butir soal adalah kemampuan suatu soal untuk membedakan antara peserta didik yang berkemampuan tinggi dengan peserta didik

$$
D=P A-P B=\frac{B A}{J A}-\frac{B B}{J B}
$$

(Arikunto 2018)

Keterangan :

yang berkemampuan rendah. Angka yang menunjukkan besarnya daya pembeda disebut Indeks diskriminasi (D). Rumus untuk menentukan indeks diskriminasi adalah :

JA : banyaknya peserta kelompok atas

JB : banyaknya peserta kelompok bawah

BA : banyaknya peserta kelompok atas yang menjawab benar

BB : banyaknya peserta kelompok bawah yang menjawab benar

PA : proporsi peserta kelompok atas yang menjawab benar

$\mathrm{PB}$ : proporsi peserta kelompok bawah yang menjawab benar

Tabel 3. Kategori Daya Pembeda Butir Soal

\begin{tabular}{cc}
\hline Batasan & Kategori \\
\hline $\mathrm{D}=$ Negatif & Jelek sekali, harus dibuang \\
\hline $0,00 \leq \mathrm{D} \leq 0,20$ & Jelek \\
\hline $0,20 \leq \mathrm{D} \leq 0,40$ & Cukup \\
\hline $0,40 \leq \mathrm{D} \leq 0,70$ & Baik \\
\hline $0,70 \leq \mathrm{D} \leq 1,00$ & Baik Sekali \\
\hline
\end{tabular}

\section{d) Tingkat Kesukaran Butir Soal}

Tingkat kesukaran butir soal diberi simbol $\mathrm{P}$ (proporsi) yang dihitung dengan rumus :

$$
P=\frac{B}{J S}
$$

(Arikunto, 2018)

Keterangan :

$\mathrm{P} \quad$ : Indeks kesukaran

B : Banyaknya peserta didik yang menjawab soal dengan betul

JS : Jumlah seluruh peserta didik peserta tes

Tabel 4. Kategori Tingkat Kesukaran Butir Soal

\begin{tabular}{cccc}
\hline No. & Tingkat Kesukaran Tes & Kategori & Keterangan \\
\hline 1. & $0,00-0,15$ & Sukar sekali & Ditolak \\
\hline 2. & $0,16-0,30$ & Sukar & Diterima \\
\hline 3. & $0,31-0,70$ & Sedang & Diterima \\
\hline 4. & $0,71-0,90$ & Mudah & Diterima \\
\hline 5. & $0,91-1,00$ & Mudah sekali & Ditolak \\
\hline
\end{tabular}


Berdasarkan soal yang telah diujicobakan, karakteristik instrumen penelitian tes hasil belajar
IPA peserta didik materi getaran, gelombang dan bunyi dapat dilihat pada Tabel 5 .

Tabel 5. Rangkuman Karakteristik Instrumen Penelitian Tes Hasil Belajar IPA Peserta Didik Materi Getaran, Gelombang Dan Bunyi

\begin{tabular}{|c|c|c|c|c|c|c|}
\hline \multirow[b]{2}{*}{ No } & \multirow[b]{2}{*}{$\begin{array}{l}\text { Variabel } \\
\text { Instrumen }\end{array}$} & \multirow{2}{*}{$\begin{array}{l}\text { Nilai/Interval } \\
\text { Nilai Uji } \\
\text { Coba }\end{array}$} & \multicolumn{3}{|c|}{ Karakteristik Instrumen } & \multirow[b]{2}{*}{ Keterangan } \\
\hline & & & $\begin{array}{c}\text { Jenis } \\
\text { Kategori }\end{array}$ & $\begin{array}{c}\text { Jumlah } \\
\text { Item }\end{array}$ & $\%$ & \\
\hline \multirow{2}{*}{1} & \multirow{2}{*}{ Validitas } & \multirow{2}{*}{$\begin{array}{l}\mathrm{R}_{\text {hit }}=-0,023 \\
\text { s/d } 0,754 \\
\mathrm{R}_{\text {tab }}=0,361\end{array}$} & Valid & 20 & 66,6 & $\begin{array}{l}1,2,3,4,5,7,9,11,12,13, \\
15,16,20,21,22,23,25,2 \\
8,29,30 \text { (Digunakan) }\end{array}$ \\
\hline & & & $\begin{array}{l}\text { Tidak } \\
\text { Valid }\end{array}$ & 10 & 33,3 & $\begin{array}{l}6,8,10,14, \\
17,18,19,24,26,27, \\
\text { (Tidak Digunakan) }\end{array}$ \\
\hline 2 & Reliabilitas & 0,726 & - & - & - & Reliabel \\
\hline \multirow{5}{*}{3} & \multirow{5}{*}{$\begin{array}{c}\text { Daya } \\
\text { Pembeda }\end{array}$} & \multirow{5}{*}{$0 \mathrm{~s} / \mathrm{d} 0,719$} & $\begin{array}{l}\text { Jelek } \\
\text { Sekali }\end{array}$ & 1 & 3,3 & 19 (Tidak Digunakan) \\
\hline & & & Jelek & 10 & 33,3 & $\begin{array}{l}6,7,, 8,10,14,17,18,24,2 \\
7 \text { (Tidak Digunakan) } \\
28 \text { (Digunakan) }\end{array}$ \\
\hline & & & Cukup & 13 & 43,3 & $\begin{array}{l}1,2,3,4,5,9,11,12,13,15 \\
16,21,25 \text { (Digunakan) } \\
26 \text { (Tidak Digunakan) }\end{array}$ \\
\hline & & & Baik & 4 & 13,3 & $\begin{array}{l}20,22,23,30 \\
\text { (Digunakan) }\end{array}$ \\
\hline & & & $\begin{array}{c}\text { Baik } \\
\text { Sekali }\end{array}$ & 1 & 3,3 & 29 (Digunakan) \\
\hline \multirow{5}{*}{4} & \multirow{5}{*}{$\begin{array}{l}\text { Tingkat } \\
\text { Kesukaran }\end{array}$} & \multirow{5}{*}{$0 \mathrm{~s} / \mathrm{d} 0,82$} & $\begin{array}{l}\text { Sangat } \\
\text { sukar }\end{array}$ & 5 & 16,6 & $\begin{array}{l}\text { 17,18,19,24,27 (tidak } \\
\text { digunakan) }\end{array}$ \\
\hline & & & sukar & 2 & 6,6 & $\begin{array}{l}10 \text { (tidak digunakan) } \\
22 \text { (digunakan) }\end{array}$ \\
\hline & & & sedang & 16 & 53,3 & $\begin{array}{l}2,3,4,5,7,9,13,16,20,25 \\
, 28,29,30 \text { (digunakan) } \\
6,8,26 \text { (tidak } \\
\text { digunakan) }\end{array}$ \\
\hline & & & mudah & 7 & 23,3 & $\begin{array}{l}1,11,12,15,21,23 \\
\text { (digunakan) } 14 \text { (tidak } \\
\text { digunakan) }\end{array}$ \\
\hline & & & $\begin{array}{l}\text { Mudah } \\
\text { sekali }\end{array}$ & - & - & - \\
\hline 5 & $\begin{array}{l}\text { Jumlah } \\
\text { Subyek }\end{array}$ & 29 & \multirow{6}{*}{\multicolumn{4}{|c|}{$\begin{array}{c}\text { Jumlah soal yang digunakan adalah } 20 \text { nomor karena } \\
10 \text { nomor pengurangan }(6,8,10,14,17,18,19,24,26,27) \\
\text { karena tidak valid }\end{array}$}} \\
\hline 6 & Jumlah Item & 30 & & & & \\
\hline 7 & $\begin{array}{c}\text { Skor } \\
\text { Maksimum }\end{array}$ & 20 & & & & \\
\hline 8 & $\begin{array}{c}\text { Skor } \\
\text { Minimum } \\
\end{array}$ & 4 & & & & \\
\hline 9 & $\begin{array}{l}\text { Skor Rata- } \\
\text { rata }\end{array}$ & 10,93 & & & & \\
\hline 10 & $\begin{array}{l}\text { Standar } \\
\text { Deviasi }\end{array}$ & 4,31 & & & & \\
\hline
\end{tabular}


HASIL PENELITIAN

1. Hasil Analisis Deskriptif Data Hasil Belajar Peserta Didik
Deskripsi hasil belajar peserta didik kelas eksperimen dan kelas kontrol dapat dilihat pada 4.1

Tabel 6. Deskripsi dan Pengkategorian Hasil Belajar Peserta Didik Kelas Eksperimen dan Kelas Kontrol.

\begin{tabular}{cccccc}
\hline $\begin{array}{c}\text { Interval } \\
\text { Nilai }\end{array}$ & \multirow{2}{*}{ Ket } & \multicolumn{2}{c}{ Kelas Eksperimen } & \multicolumn{2}{c}{ Kelas Kontrol } \\
\cline { 3 - 6 } & & Tes Awal & Tes Akhir & Tes Awal & Tes Akhir \\
\hline $0-20$ & Gagal & 1 & 0 & 1 & 0 \\
\hline $21-40$ & Kurang & 13 & 0 & 15 & 2 \\
\hline $41-60$ & Cukup & 12 & 11 & 11 & 18 \\
\hline $61-80$ & Baik & 2 & 16 & 1 & 6 \\
\hline $81-100$ & Sangat Baik & 0 & 1 & 0 & 2 \\
\hline \multicolumn{2}{r}{ Max } & 70 & 90 & 65 & 85 \\
\hline Min & 15 & 50 & 15 & 25 \\
\hline Mean & 42.86 & 65.18 & 42.14 & 57.5 \\
\hline Modus & 40 & 65 & 35 & 10 \\
\hline SD & 14.1 & 10.04 & 12.8 & 13.78 \\
\hline
\end{tabular}

Tabel 7. Pengkategorian Hasil Belajar Peserta Didik Kelas Eksperimen dan Kelas Kontrol.

\begin{tabular}{|c|c|c|c|c|}
\hline \multirow[b]{2}{*}{ Interval Nilai } & \multicolumn{2}{|c|}{ Kelas Eksperimen } & \multicolumn{2}{|c|}{ Kelas Kontrol } \\
\hline & $\frac{N \text {-gain }}{F}$ & Ket & $\frac{N \text {-gain }}{f}$ & Ket \\
\hline $0,70<\mathrm{N}$-gain & 2 & Tinggi & 1 & Tinggi \\
\hline $0,30<=\mathrm{N}$-gain $<=0,70$ & 20 & Sedang & 9 & Sedang \\
\hline $\mathrm{N}$-gain $<0,30$ & 6 & Rendah & 18 & Rendah \\
\hline $\operatorname{Max}$ & 0.75 & Tinggi & 0.571 & Sedang \\
\hline Min & -0.25 & Rendah & -0.1 & Rendah \\
\hline Mean & 0.373 & Sedang & 0.269 & Rendah \\
\hline Modus & 0.4667 & Sedang & 50 & Rendah \\
\hline SD & 0.198 & Rendah & 0.173 & Rendah \\
\hline
\end{tabular}

Dari tabel di atas diperoleh informasi bahwa peserta didik yang paling banyak masuk dalam kriteria kurang untuk tes awal kelas eksperimen yaitu 13 orang, dan kriteria baik untuk tes akhir kelas eksperimen yang paling banyak yaitu 16 orang. Sedangkan untuk kelas kontrol tes awal dalam kriteria yang paling banyak yaitu kurang 15 orang dan untuk tes akhir yang paling banyak yaitu kriteria cukup 18 orang. Salian itu nilai rata-rata pretes, posttes kelas eksperimen dan jauh lebih tinggi dibandingkan dengan kelas kontrol, Namun keduanya mengalami peningkatan. Pada Tabel 4.2 diperoleh informasi bahwa $N$-gain kelas eksperimen lebih tinggi dibandingkan dengan kelas kontrol. Selengkapnya Peningkatan hasil belajar peserta didik dapat dilihat pada Gambar 1 berikut. 


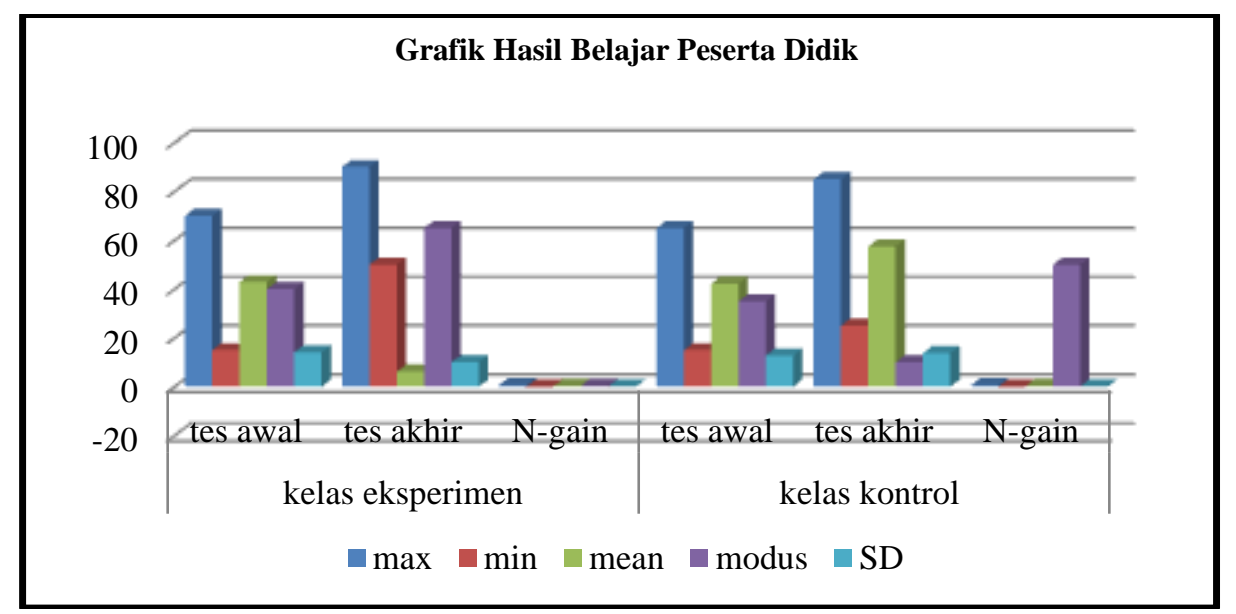

Gambar 1. Grafik Peningkatan Hasil Belajar Peserta Didik

2. Hasil Pengujian Normalitas dan Homogenitas

Pengujian normalitas data dilakukan dengan menggunakan uji statistik Kolmogorov-Smirnov
(KS) dan pengujian homogenitas data dilakukan dengan menggunakan uji Levene. Dalam penelitian ini digunakan taraf signifikan $\alpha=0,05$.

Tabel 8. Hasil Pengujian Normalitas Data Hasil Belajar Peserta Didik

\begin{tabular}{|c|c|c|c|c|c|c|}
\hline \multirow{2}{*}{ Variabel } & \multirow{2}{*}{$\begin{array}{c}\text { Model } \\
\text { Pembelajaran }\end{array}$} & \multicolumn{4}{|c|}{ Signifikansi } & \multirow{2}{*}{ Keputusan } \\
\hline & & $\mathbf{N}$ & Pretes & Posttes & $\alpha$ & \\
\hline \multirow{2}{*}{$\begin{array}{l}\text { Hasil } \\
\text { Belajar } \\
\text { Peserta } \\
\text { Didik }\end{array}$} & $\begin{array}{c}\text { Inkuiri } \\
\text { Terbimbing }\end{array}$ & 28 & 0,877 & 0,129 & \multirow[b]{2}{*}{0,05} & $\begin{array}{l}\text { Berdistribusi } \\
\text { Normal }\end{array}$ \\
\hline & Konvensional & 28 & 0,920 & 0,385 & & $\begin{array}{c}\text { Berdistribusi } \\
\text { Normal }\end{array}$ \\
\hline
\end{tabular}

Berdasarkan hasil uji normalitas data di atas karena probabilitas alpha pada taraf kepercayaan $95 \%(\alpha=0,05)$. semua data tes awal dan tes akhir untuk kelas eksperimen dan kelas kontrol berdistribusi normal

Tabel 9. Hasil Pengujian Homogenitas Data Hasil Belajar Peserta Didik

\begin{tabular}{cccc}
\hline \multirow{2}{*}{ Aspek } & \multicolumn{2}{c}{ Signifikansi } & \multirow{2}{*}{ Keputusan } \\
\cline { 2 - 2 } Pretes & Probabilitas & $\boldsymbol{\alpha}$ & \\
\hline Posttes & 0,649 & & Homogen \\
\hline$N$-Gain & 0,085 & 0,05 & Homogen \\
& 0,609 & & Homogen \\
\hline
\end{tabular}

Berdasarkan hasil uji homogenitas varians data di atas semua diperoleh varians data tes awal, tes akhir, dan $N$-gain untuk kelas eksperimen dan kelas kontrol berdistribusi homogen karena probabilitas>alpha pada taraf kepercayaan $95 \%$ $(\alpha=0,05)$.

\section{Hasil Pengujian Hipotesis Penelitian}

Pengujian hipotesis menggunakan uji-t untuk perbedaan nilai pretest dan posttest mengenai perbedaan nilai $N$-gain hasil belajar peserta didik menggunakan model pembelajaran inkuiri terbimbing dan Konvensional disajikan pada Tabel 10. 
Tabel 10. Hasil Pengujian Hipotesis Nilai Pretest, Posttest dan N-gain Hasil Belajar Peserta Didik Terhadap Model Pembelajaran Inkuiri Terbimbing dan Konvensional.

\begin{tabular}{|c|c|c|c|c|c|c|}
\hline \multirow{2}{*}{ Variabel } & \multirow{2}{*}{ Aspek } & \multicolumn{3}{|c|}{ Independent Samples Test } & \multirow{2}{*}{$\alpha$} & \multirow{2}{*}{ Keputusan } \\
\hline & & $\mathbf{t}_{\text {hit }}$ & $t_{\text {tab }}$ & Asymp.Sig & & \\
\hline \multirow{3}{*}{$\begin{array}{l}\text { Hasil belajar } \\
\text { peserta didik }\end{array}$} & H1 & 0,198 & \multirow{3}{*}{2,004} & 0,843 & \multirow{3}{*}{0,05} & $\mathrm{H}_{0}$ diterima \\
\hline & $\mathrm{H} 2$ & 2,383 & & 0,021 & & $\mathrm{H}_{0}$ ditolak \\
\hline & $\mathrm{H} 3$ & 2,094 & & 0,041 & & $\mathrm{H}_{0}$ ditolak \\
\hline
\end{tabular}

Berdasarkan Tabel di atas, diperoleh informasi bahwa hasil uji hipotesis $\mathrm{H} 1, \mathrm{H}_{0}$ diterima artinya tidak ada perbedaan antara nilai pretest peserta didik antara kelas eksperimen dan kelas kontrol. $\mathrm{H} 2, \mathrm{H}_{0}$ ditolak artinya ada perbedaan antara nilai tes akhir dari peserta didik yang menerapkan pembelajaran inkuiri terbimbing dari pembelajaran konvensional. Serta $\mathrm{H} 3, \mathrm{H}_{0}$ ditolak artinya nilai rata-rata $\mathrm{N}$-gain hasil belajar peserta didik kelas eksperimen lebih tinggi dari pada kelas kontrol. Perhitungan hasil pengujian hipotesis data penelitian secara lengkap dapat dilihat pada Lampiran 16 serta lampiran 20 untuk titik persentase distribusi t.

\section{PEMBAHASAN}

Berdasarkan hasil belajar peserta didik dengan model pembelajaran inkuiri terbimbing bahwa belum sangat baik di laksanakan. Hasil belajar peserta didik ditentukan oleh beberapa faktor, faktor dari dalam diri peserta didik maupun dari luar peserta didik. Selain itu yang menentukan hasil belajar peserta didik yaitu proses belajar mengajar di dalam kelas. Interaksi antara guru dengan peserta didik sangat mendukung terjadinya proses belajar mengajar. Pada bagian ini dibahas tentang peningkatan hasil belajar peserta didik dengan pembelajaran inkuiri terbimbing.

Pembelajaran di sekolah yang dilakukan di SMPN 22 Konawe Selatan berdasarkan observasi dan wawancara bahwa guru menggunakan pembelajaran konvensional. Dimana peserta didik hanya mendapatkan ilmu dari guru bukan dari dirinya sendiri. Sehingga sangat penting di gunakan pembelajaran inkuiri terbimbing karena dapat meningkatkan aktivitas peserta didik dan melatih keterampilan peserta didik dalam proses dan menggali informasi sehingga hasil belajar yang diperoleh peserta didik lebih meningkat.

Model pembelajaran inkuiri terbimbing selama ini bisa membuat peserta didik mengalami sendiri pengetahuan, dibandingkan dengan pembelajaran konvensional. Untuk mengetahui perbandingan dari kedua pembelajaran tersebut, maka sebelum dan sesudah pembelajaran di lakukan tes hasil belajar peserta didik untuk mengetahui peningkatan hasil belajar peserta didik antara model pembelajaran inkuiri terbimbing dan model pembelajaran konvensional. Dari analisis data hasil belajar peserta didik mengalami peningkatan. Hal ini terlihat ketika pada awalnya banyak peserta didik yang mengalami kesulitan untuk mengikuti proses pembelajaran, akan tetapi untuk selanjutnya sebagian besar peserta didik mulai dapat mengikuti proses pembelajaran dengan baik.

Peningkatan hasil belajar peserta didik yang baik pada Tabel 4.1 bahwa ada lima kategori yaitu gagal dengan interval nilai 0-20, kurang 21-40, cukup 41-60, baik 61-80, sangat baik 81-100. Pengkategorian untuk kelas eksperimen pada tes awal peserta didik dalam kategori gagal berjumlah 1 peserta didik namum untuk tes akhirnya mengalami peningkatan yaitu tidak ada peserta didik yang dikatakan gagal. Begitu pula dengan kategori kurang, kategori cukup untuk tes awal sebanyak 12 peserta didik pada tes akhir berkurang namun meningkat dalam kategori baik yaitu dari 2 peserta didik menjadi 16 peserta didik dalam kategori baik dan untuk kategori sangat baik pada tes awal tidak ada namun pada tes akhir menjadi 1 peserta didik yang mendapat kategori sangat baik.

Hasil belajar peserta didik untuk kelas kontrol dikatakan dalam kategori gagal untuk tes awal berjumlah 1 peserta didik pada tes akhir menjadi 0 , untuk kategori kurang tes awal berjumlah 15 peserta didik pada tes akhinya menjadi 2. Kategori cukup pada tes awal berjumlah 11 peserta didik meningkat di tes akhir menjadi 18 , dalam kategori baik untuk tes awal berjumlah 1 peserta didik pada tes akhir menjadi 6 peserta didik. Kategori sangat baik pada tes awal berjumlah 0 namun untuk tes akhir menjadi 2 peserta didik. Sehingga jika dibandingkan kelas eksperimen dengan kelas kontrol yang lebih mengalami peningkatan yaitu pada kelas eksperimen. Hal ini di karenakan pada kelas eksperimen menggunakan pembelajaran inkuiri terbimbing dimana peserta didik dalam pembelajarannya lebih aktif. 
Selain itu nilai maksimum 70 , nilai minimum 15, rata-rata 42,86 dan standar deviasi 14,1 . Sedangkan peserta didik dengan pembelajaran dengan model pembelajaran konvensional diperoleh nilai maksimum 65 , nilai minimum 15 , rata-rata 42,14 dan standar deviasi 12,8. Dan hasil tes akhir peserta didik dengan model pembelajaran inkuiri terbimbing diperoleh nilai maksimum 90, nilai minimum 50, rata-rata 65,18 dan standar deviasi 10,4. Sedangkan pada peserta didik dengan model pembelajaran konvensional diperoleh nilai maksimum 85 , nilai minimum 25 , rata-rata 57,5 dan standar deviasi 13,78. Dari data tersebut dapat digambarkan hasil belajar peserta didik dengan model pembelajaran inkuiri terbimbing sudah baik.

Berdasarkan Tabel 4.2 di peroleh informasi $N$ gain pada kelas eksperimen dalam kategori tinggi berjumlah 2 peserta didik namun kelas kontrol berjumlah 1, kategori sedang kelas eksperimen berjumlah 20 peserta didik kelas kontrol 9 peserta didik dan untuk kategori rendah kelas eksperimen berjumlah 6 peserta didik pada kelas kontrol berjumlah 18 peserta didik. $N$-gain antara kelas eksperimen dan kontrol cukup jelas bahwa peningkatan hasil belajar kelas eksperimen jauh lebih baik dibandingkan kelas kontrol. Selain itu juga dari $\mathrm{N}$-gain maksimum, minimum, mean, dan standar deviasi kelas eksperimen jauh lebih tinggi dibandingkan kelas eksperimen. Sehingga dapat digambarkan bahwa pembelajaran inkuiri terbimbing dapat meningkatkan hasil belajar peserta didik

Berdasarkan data tes awal hasil belajar peserta didik menunjukkan bahwa nilai rata-rata peserta didik kelas VIII B sebagai kelas eksperimen 42,86 sedangkan untuk kelas VIII C sebagai kelas kontrol 42,14. Hal ini menunjukkan bahwa sebelum diberi perlakuan kedua kelas tersebut, kelasVIII B pencapainya lebih tinggi dibandingkan kelas VIII C. hal ini karena materi belum pernah diajarkan kepada peserta didik sehingga peserta didik hanya menebak saja sesuai dengan pengalaman atau pengetahuan yang seadanya saja.

Pada tes akhir menunjukkan bahwa nilai ratarata kelas yang diajarkan melalui pembelajaran inkuiri terbimbing lebih tinggi dibandingkan dengan kelas yang diajarkan dengan pembelajaran konvensional. Hal tersebut dilihat dari nilai rata-rata yang diperoleh sebesar 65,18 sedangkan untuk kelas kontrol sebesar 57,5. Perbedaan nilai rata-rata tes akhir peserta didik melalui pembelajaran inkuiri terbimbing dengan pembelajaran konvensional disebabkan karena kelas yang menggunakan model pembelajaran inkuiri terbimbing, dimana dalam pembelajarannya peserta didik dapat mengkonstruk sendiri pengetahuan mereka melalui percobaan yang telah dikerjakan. Namun, meskipun ketercapaian nilai hasil belajar tes akhir peserta didik berbeda keduan model ini sama-sama dapat meningkatkan hasilbelajar peserta didik. Hal ini sesuai dengan pernyataan Chairinda dkk (2017) bahwa pembelajaran menggunakan inkuiri terbimbing terbukti dapat meningkatkan hasil belajar peserta didik baik ketuntasan secara individual maupun secara klasikal. Sama halnya dengan model pembelajaran inkuiri terbimbing, Ibrahim (2017) yang menyatakan bahwa hasil belajar setelah dilakukan tindakan kolaborasi antara model pembelajaran konvensional metode ceramah dengan model pembelajaran metode Make-A Match mengalami peningkatan terhadap hasil belajar peserta didik. Hal ini dikarenakan kekompakan bisa terbangun saat diskusi, semangat belajar tinggi karena sambil bermain, pencapaian materi secara umum lebih mudah dan suasana kelas lebih hidup. Walaupun demikian berdasarkan standar deviasi yang diperoleh dari keduan kelas, untuk kelas eksperimen sudah cukup baik karena standar deviasi tes akhir lebih kecil dibandingkan tes awal. Dapat disimpulkan bahwa tingkat kesalahan peserta didik dalam mengerjakan soal pada tes akhir lebih sedikit dibandingkan tes awal. Berbeda dengan kelas kontrol standar deviasi tes akhir lebih besar dibandingkan tes awal sehingga, dapat dikatakan begitu banyak penyimpangan yang terjadi pada hasil belajar tinggi peserta didik artinya hanya beberapa peserta didik yang begitu terlihat mampu dan menonjol pada pembelajaran dan dalam mengerjakan soal.

Hasil pengujian inferensial nilai rata-rata $\mathrm{N}$ gain untuk kelas eksperimen sebesar 0,373 (kategori sedang). Sedangkan nilai rata-rata $\mathrm{N}$-gain kelas kontrol sebesar 0,269 (kategor rendah). Oleh karena itu dapat diketahui bahwa pada kelas eksperimen yang menerapkan model pembelajaran inkuiri terbimbing nilai $\mathrm{N}$-gain mendapatkan kategori yang lebih tinggi dibandingkan pada kelas kontrol yang menerapkan model pembelajaran konvensional. Ini menunjukkan bahwa pada kelas yang menerapkan pembelajaran inkuiri terbimbing lebih mudah diterima dari pada yang menerapkan pembelajaran konvensional. Sehingga dapat disimpulkan bahwa pembelajaran pada kelas eksperimen lebih baik dibandingkan pembelajaran pada kelas kontrol. Ini dikerenakan pembelajaran pada kelas eksperimen menggunakan pembelajaran inkuiri terbimbing, 
dimana dalam pembelajaran ini siswa di ajak secara aktif dalam belajar serta aktif melakukan praktikum. Dalam melakukan praktikum peserta didik merencanakan dan mengerjakan sendiri serta mendiskusikan masalah yang dihadapi bersama anggota kelompoknya, dan guru sebagai fasilitator untuk membantu peserta didik dalam mengerjakan kesulitan yang dihadapi.

Dari hasil penelitian ini sebagaimana telah dikemukakan pada bagian sebelumnya, memberikan gambaran bahwa model pembelajaran inkuiri terbimbing dapat memberikan sumbangan yang lebih baik terhadap hasil belajar peserta didik dibandingkan dengan pembelajaran konvensional, sehingga peserta didik mampu mengaplikasikan dalam kehidupan sehari-hari pembelajaran yang diperoleh dari proses belajar. Pada akhirnya diharapkan peserta didik menjadi lebih paham terhadap materi pelajaran yang dipelajarinya, sehingga berdampak positif terhadap prestasi belajar serta hasil belajar peserta didik. Sama halnya yang dikemukakan sumarni (2017) mengenai penerapan model pembelajaran inkuiri terbimbing lebih baik dibandingkan dengan pembelajaran konvensional.

\section{KESIMPULAN}

Gambaran hasil tes awal peserta didik dengan model pembelajaran inquiri terbimbing pada materi getaran, gelombang dan bunyi diperoleh nilai maksimum 70 , nilai minimum 15 , rata-rata 42,86 dan standar deviasi 14,1. Sedangkan peserta didik dengan pembelajaran dengan model pembelajaran konvensional diperoleh nilai maksimum 65 , nilai minimum 15 , rata-rata 42,14 dan standar deviasi 12,8. Gambaran hasil tes akhir peserta didik dengan model pembelajaran inquiri terbimbing diperoleh nilai maksimum 90 , nilai minimum 50 , rata-rata 65,18 dan standar deviasi 10,4. Sedangkan pada peserta didik dengan model pembelajaran konvensional diperoleh nilai maksimum 85 , nilai minimum 25, rata-rata 57,5 dan standar deviasi 13,78. Tidak ada perbedaan antara nilai rata-rata hasil tes awal peserta didik kelas eksperimen dan kelas kontrol. Ada perbedaan antara nilai rata-rata hasil tes akhir peserta didik kelas eksperimen dan kelas kontrol. Nilai rata-rata $\mathrm{N}$-gain peserta didik kelas eksperimen lebih tinggi dari pada kelas kontrol.

\section{DAFTAR PUSTAKA}

Afandi Muhamad, S.Pd.,M.Pd. 2013. Model dan Metode Pembelajaran Di Sekolah. Semarang : Unissula Press.

Alamsyah Mashudi, M.Pd. 2011. Teori Belajar dan Pembelajaran. Jakarta: Universitas Indraprasta PGRI.

Pengembangan. Kencana Prenadamedia Group. Jakarta.

Arikunto. S. 2010. Dasar-dasar Evaluasi Pendidikan Edisi Revisi. Jakarta. PT. Bumi Aksara.

--------. 2018. Dasar-dasar Evaluasi Pendidikan Edisi kedua. Jakarta. Pt Bumi Aksara.

Siswanto, S.AP.,MM.Dr. 2017. Penilaian dan Pengukuran Sikap dan Hasil Belajar Peserta Didik. Klaten Selatan: BOSSSCRIPT

Sudjana, N. 2015. Penilaian hasil proses belajar mengajar. Bandung: Pt Remaja Rosdakarya.

Sugiyono Prof. Dr. 2013. Metode Penelitian Kuantitatif Kualitatif dan $R \& D$. Bandung : Alfabeta

Usman \& Setiawati. 2001. Statistika. Bandung: Remaja Rosdakarya.

Amroniyah Syarifatun. 2015. Upaya Peningkatan Prestasi Belajar IPA materi Getaran dan Gelombang Melalui penerapan Model pembelajaran inkuiri Terbimbing Pada Siswa Kelas VIII MTs Muallimin Malebo Kandangan Temanggung Tahun Ajaran 2014/2015. Universitas Islam Negeri Walisongo. Semarang.

Fatmawati. 2013. Keefektifan Model Pembelajaran Inkuiri Dan Model Pembelajaran Langsung Terhadap Hasil Belajar Peserta Didik Pada Sub Materi Pokok Fluida Statis Kelas Xi Ipa Sma Negeri I Lawa. Universitas Halu Oleo. Kendari

Ibrahim. 2017. Perpaduan Modelpembelajaran Aktif

Konvensional (Ceramah) Dengan Cooperatif (Make-A Match) Untukmeningkatkan Hasilbelajar Pendidikan Kewarganegaraan. Bengkalis. SDN 11 Jankang.

Chairinda, dkk. 2017. Penerapan Model Pembelajaran Inkuiri Terbimbing Untuk Meningkatkan Hasil Belajar Siswa Kelas XI MIA 1 Pada Materi Getaran Harmonis Di SMAN 12 Banda Aceh. Unsyiah. 
Pendidikan Fisika Fakultas Keguruan dan Ilmu Pendidikan.

Imaniarti Eviana dkk. 2015. Penerapan Model Pemebelajaran Inkuiri Terbimbing Disertai Teknik Mind Mapping Terhadap Kemampuan Kognitif, Afektif, dan Psikomotorik Siswa Dalam Pembelajaran Fisika Di SMAN Arjasa. Universitas Jember. Jember.

Iswatuna I dkk. 2017. Penerapan model Pembelajaran Inkuiri Terbimbing untuk Meningkatkan KPS dan Hasil Belajar Siswa SMP Kelas VIII. Universitas Negeri Semarang. Semarang.

Putri Desy Qoraima dkk. 2016. Penerapan Model Pembelajaran Inkuiri Terbimbing untuk Meningkatkan Aktivitas Belajar Siswa dan Hasil Belajar Siswa Kelas X PHP (Pengolahan Hasil Pertanian) Di SMK Negeri 5 Jember. Universitas Jember. Jember.

Retnosari Nilam dkk. 2016. Pengaruh Model Pembelajaran Inkuiri Terbimbing Berbantuan Multimedia Interaktif Terhadap Berpikir Kritis Siswa Kelas XI SMA Negeri Di Bojonegoro. Universitas Negeri Malang. Semarang.

Sari. Nirta Mala. 2017. Pengaruh Model Pembelajaran Inkuiri Terbimbing Terhadap Peningkatan Keterampilan
Proses Sains dan Sikap Ilmiah Peserta Didik Kelas XI pada Mata Pelajaran Biologi Di SMA YP Unila Bandar Lampung. Universitas Islam Negeri (UIN). Lampung.

Sukma dkk. 2016. Pengaruh Model Pembelajaran Inkuiri Terbimbing (Guided Inquiry) dan Motivasi Terhadap Hasil Belajar Fisika Siswa. Universitas Mulawarman. Samarinda-Indonesia.

Sumarni dkk. 2017. Pengaruh Model Pembelajaran Inkuiri Terbimbing Terhadap Hasil Belajar Kognitif Peserta Didik Di Sma Negeri 01 Manokwari (Studi Pada Pokok Bahasan Kelarutan dan Hasil Kali Kelarutan). Universitas Papua Manokwari. Manokwari Papua Barat.

Wahyuni Roni dkk. 2016. Pengaruh Model Pembelajaran Inkuiri Terbimbing dengan Metode Eksperimen Terhadap Hasil belajar Fisika Siswa Kelas XI IPA SMAN 2 Mataram Tahun Pelajaran 2016/2017. Universitas Mataram. Mataram.

Meltzer, D.E. 2002. 'The Relationship Between Mathematics Preparation and Conceptual Learning Gains in Physics: Possible "Hidden Variable" in Diagnostic Pretest Scores'. American Journal of Physics. Vol. 10, no. 2, hlm 35 . 